\title{
CORRIGENDUM
}

\section{Endogenous Arabidopsis messenger RNAs transported to distant tissues}

Christoph J. Thieme, Monica Rojas-Triana, Ewelina Stecyk, Christian Schudoma, Wenna Zhang, Lei Yang, Miguel Miñambres, Dirk Walther, Waltraud X. Schulze, Javier Paz-Ares, Wolf-Rüdiger Scheible and Friedrich Kragler

Nature Plants 1, 15025 (2015); published online 23 March 2015; corrected 28 May 2015

In Figure $3 \mathrm{e}$ of the version of this Article originally published, the wt/wt control graft and $c k 1.2 / c k 1.2$ mutant control graft were mislabelled. This error has been corrected. 